\title{
Timing of glaciation in the Mediterranean mountains during the last cold stage
}

\author{
PHILIP D. HUGHES* and JAMIE C. WOODWARD \\ Geography, School of Environment and Development, The University of Manchester, Manchester, UK
}

Hughes, P. D. and Woodward, J. C. 2008. Timing of glaciation in the Mediterranean mountains during the last cold stage. J. Quaternary Sci., Vol. 23 pp. 575-588. ISSN 0267-8179.

Received 4 June 2007; Revised 22 April 2008; Accepted 9 May 2008

\begin{abstract}
Recent research in the mountains of the Mediterranean has attempted to establish the timing of the maximum extent of glaciers during the last cold stage. Several dating methods have been utilised and new dating frameworks have emerged in key areas. In several places, multiple dating techniques (radiocarbon, optically stimulated luminescence, U-series) applied to glacial and associated sediments suggest that local glacier maxima preceded the global Last Glacial Maximum (LGM, ca. $18{ }^{14} \mathrm{C}$ ka BP/ 21 cal. ka BP) by at least several thousand years. Studies in Spain, the Pyrenees, the Maritime Alps and Turkey utilising cosmogenic isotope analyses $\left({ }^{10} \mathrm{Be}\right.$ and $\left.{ }^{36} \mathrm{Cl}\right)$, have yielded glacial geochronologies with maxima that correlate closely with the marine isotope record of ice volume and the global LGM. In some cases, the use of different geochronological techniques has led to conflicting evidence for the timing of the local last glacier maxima in the same area. From a palaeoclimate perspective, glacier-climate reconstructions for the local last glacier maxima in the mountains of central Italy, northern Greece and western Turkey indicate that climate was wet and cold. In Italy and Greece the local glacier maxima preceded the driest part of the last cold stage - as indicated by palaeoecological records - by several thousand years. For western Turkey, however, recent cosmogenic exposure ages combined with glacier modelling suggest a local last glacier maximum characterised by cold and wet conditions coinciding with the global LGM. The available evidence indicates that a dichotomy is emerging, not only in our understanding of the timing of glaciation across the Mediterranean, but also in the palaeoclimatic interpretations derived from glacial and palaeoecological records. Copyright (C) 2008 John Wiley \& Sons, Ltd.
\end{abstract}

KEYWORDS: Mediterranean; glaciers; glaciation; Late Pleistocene; geochronology; dating.

\section{Introduction}

The nature of cold-stage climates in the Mediterranean region has been the focus of much research in recent decades, with particular emphasis on the last cold stage (Marine Isotope Stage (MIS) 5d-2; Alpine chronostratigraphy - Würmian Stage). Long lacustrine sequences from tectonic and volcanic basins and speleothem records have provided much of the terrestrial evidence for former environmental conditions (Tzedakis et al., 1997; Allen et al., 1999; Bar Matthews et al., 1999). However, the timing of glacial activity in the Mediterranean mountains during the last cold stage has proved difficult to establish (Hughes et al., 2006a). Progress has been made using radiocarbon dating of lacustrine deposits within former glacier limits (e.g. González-Sampériz et al., 2006) and uranium series dating of fluvial deposits in valleys downstream of former glaciation (e.g. Lewin et al., 1991; Woodward et al., 2008). It is only very recently, however, that well-dated records have been

* Correspondence to: P. D. Hughes, School of Environment and Development, The University of Manchester, Manchester M13 9PL, UK.

E-mail: philip.hughes@manchester.ac.uk

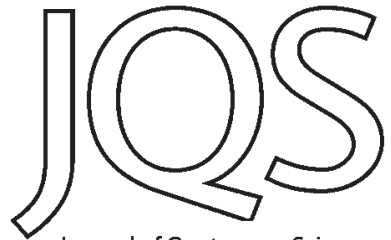

Journal of Quaternary Science obtained from the glacial sediments and landforms themselves. In addition, recent developments in cosmogenic isotope analyses have led to some of the first publications of exposure ages for glacial features in the Mediterranean (e.g. Akçar et al., 2007).

This paper reviews the available glacial geochronological data from the Mediterranean mountains for the last cold stage, including the Younger Dryas, and examines the evidence for glacier advances in conjunction with other records of regional and global climate change. This paper forms part of the INQUA Mountain Glacier Research Project 'Timing and Nature of Mountain Glacier Advances, from 5e to YD'. We examine the timing of glacier development across the Mediterranean and consider regional glacier dynamics in relation to the Last Glacial Maximum. This global stratigraphical event is abbreviated LGM in this paper and occurred at ca. $18{ }^{14} \mathrm{C}$ ka BP or ca. 21 cal. ka BP (cf. CLIMAP Project Members, 1976; Martinson et al., 1987; COHMAP Members, 1988; Yokoyama et al., 2000).

Middle Pleistocene glacier activity has been recognised in several Mediterranean mountain areas, including north-west Spain, the Pyrenees, the Italian Apennines and the Pindus Mountains of Greece (Fernadez Mosquera et al., 2000; Kotarba 
et al., 2001; Peña et al., 2004; Woodward et al., 2004; Hughes et al., 2006b). In all of these areas the Late Pleistocene glaciations appear to have been significantly smaller than during the Middle Pleistocene cold stages. In some places, such as western and northeastern Turkey, evidence of glacial deposits older than the Late Pleistocene has not yet been found (Akçar et al., 2008; Sarıkaya et al., 2008). Attempts to establish the timing of glacier activity during the last cold stage in the Mediterranean mountains have involved a range of techniques including radiocarbon, luminescence (thermoluminescence and optically stimulated luminescence (OSL)) and cosmogenic nuclide analyses. The timing of glaciation during the last glacial cycle has also been inferred from the dating of related sediments, such as those in fluvial sequences downstream of glaciated areas. The geochronology of glaciation during the last cold stage is reviewed below with reference to individual mountain areas surrounding the Mediterranean Sea. These glaciers were small compared to the glaciers in the Alps and elsewhere in Europe during the Late Pleistocene, but their small surface areas and southerly latitude made them especially sensitive to climate change. The European Alps are beyond the scope of this paper, but we include the Maritime Alps because of their very close proximity to the Mediterranean littoral at the Côte d'Azur (Fig. 1).

\section{Glacial geochronology}

\section{Iberia: Spain and Portugal}

Until recently, there was limited geochronological control on the timing of Pleistocene glaciations in Spain and Portugal. Dating frameworks now exist for glacial sediments and landforms in the mountains of northwest Iberia, central Spain and the Cantabrian Mountains (Fig. 1).

Jiménez-Sanchez and Farias (2002) provided the first numerical age determinations (using radiocarbon dating) to establish the chronology of glacial phases in the Redes Natural Park of the Cantabrian Mountains. The most extensive glacial phase here was characterised by an ice field with outlet glaciers extending up to $5 \mathrm{~km}$ in length, descending to ca. $950 \mathrm{~m}$ above sea level (a.s.l.) with snowlines at ca. $1550 \mathrm{~m}$ a.s.l. A radiocarbon date of $28.99 \pm 0.23{ }^{14} \mathrm{C}$ ka $\mathrm{BP}(34.177 \pm 0.516$ cal. ka BP) was obtained for this glacial phase from a core retrieved from ice-dammed lacustrine deposits that formed when drainage was blocked by a lateral moraine. This provides a minimum age for the presence of glacier ice. Furthermore, radiometric dating of proglacial deposits, interpreted as being synchronous with the local last glacier maximum in the nearby Comella basin of the Picos de Europa, yielded an age of $40.48 \pm 0.82{ }^{14} \mathrm{C}$ ka BP. These dates, from the Redes Natural Park and the Picos de Europa, imply that the maximum phase of glaciation during the last glacial stage took place much earlier than the global LGM.

In central Spain, Palacios et al. (2007) have reported ${ }^{36} \mathrm{Cl}$ exposure ages for glacial landforms in the Sierra de Gredos and Sierra de Guadarrama. These dates place the local glacier maximum in these mountains at ca. $21 \mathrm{ka}-$ around the time of the global LGM. No earlier glacial formations were found in this area, in contrast to the record from northwest Iberia discussed below.

In the Serra da Estrela, the highest mountains of Portugal (1991 $\mathrm{m}$ a.s.I.) (Fig. 1), glaciation during the last cold stage was characterised by a plateau ice cap which fed diffluent glaciers, the longest of which was $13 \mathrm{~km}$ (Daveau, 1971). Thermo- luminescence dates from glaciofluvial sediments of between $16.6 \pm 2.5$ and $10.6 \pm 1.6 \mathrm{ka}$ BP suggest glacial activity during the Lateglacial (Vieira et al., 2001). These were the first radiometric ages to be published on the Estrela glaciations, although the precise timing of the last local glacial maximum in this region has not yet been established.

Further north in the Quiexa (Galicia, Spain) and Geres (Portugal) massifs (Fig. 1), ${ }^{21} \mathrm{Ne}$ cosmogenic isotope analyses $(n=5)$ have been applied to date glacially polished bedrock surfaces and push-moraine boulders (Vidal-Romaní et al., 1999; Fernadez Mosquera et al., 2000). Three glacial phases have been identified. The oldest was dated to before ca. $238 \pm 17 \mathrm{ka}$, an intermediate phase to ca. $131 \pm 17 \mathrm{ka}$ and the youngest to ca. $15 \pm 7 \mathrm{ka}$. The youngest age is supported by a radiocarbon date of $13.4 \pm 0.4{ }^{14} \mathrm{C}$ ka for the base of lacustrine sediments from a glacial lake in the same area (Vidal-Romaní and Santos, 1994). These later dates also provide support for the thermoluminescence ages of Vieira et al. (2001) from the Estrela massif, but none of the dates provide a clear picture of the timing of the last glacial maximum in this area.

\section{The Pyrenees}

Several studies from lake and bog sequences within former glacier limits on both the northern and southern slope of the Pyrenees have produced radiocarbon ages suggesting maximum glacier advances that were asynchronous with the record of global ice volume - in several areas preceding the global LGM by tens of thousands of years (e.g. Mardones and Jalut, 1983; Andrieu et al., 1988; Jalut et al., 1988, 1992; Reille and Andrieu, 1995; García Ruiz et al., 2003; González-Sampériz et al., 2006). Some of the oldest radiocarbon ages were presented by Mardones and Jalut (1983) and Andrieu et al. (1988) from the Pau valley on the northern slope of the Pyrenees. Here a date of $38.4{ }^{14} \mathrm{C}$ ka BP was obtained near the base of a lacustrine sequence within piedmont moraines. Mardones and Jalut (1983) extrapolated this date to the base of the lacustrine sequence and calculated the onset of deposition at ca. $45{ }^{14} \mathrm{C}$ ka BP and suggested an age of between 70 and 50 ${ }^{14} \mathrm{C}$ ka BP for the piedmont moraines. The validity of an early last glacier maximum in the Pyrenees has been questioned by Turner and Hannon (1988, p. 56) who noted: 'Extraordinarily, Mardones and Jalut (1983) accept these as true dates of the deposits.' Nonetheless, similar findings have been reported elsewhere in the region, such as at the Llestui glacial lake in the Ribagorçana Valley in the south-central Pyrenees. Here, Vilaplana (1983) presented radiocarbon dates of between 34 and $31.5{ }^{14} \mathrm{C}$ ka BP. An early glacier maximum in the Pyrenees during the last cold stage was also proposed by Bordonnau (1992), who placed the maximum at ca. $60{ }^{14} \mathrm{C}$ ka BP and by Montserrat (1992), who placed the maximum between 50 and $45{ }^{14} \mathrm{C}$ ka BP. Turner and Hannon (1988, p. 57) suggested that the old ${ }^{14} \mathrm{C}$ ages, first reported in Mardones and Jalut (1983), are likely to have been affected by hard-water error or possibly a mixture of reworked organic matter - a view reiterated by Pallàs et al. (2007).

Despite the issues of reliability that plague the early glacial geochronologies based on dates at the limit of the radiocarbon method, more recent studies do corroborate the idea of an early glacier maximum in the Pyrenees. For example, García-Ruiz et al. (2003) and González-Sampériz et al. (2006) presented radiocarbon dates from glacial lake sediments in the Upper Gállego Valley in the central Spanish Pyrenees. A date of $28.3 \pm 0.37{ }^{14} \mathrm{C}$ ka BP (ca. 32977 cal. ka BP) derived from pollen concentrate from the base of lacustrine sediments resting 

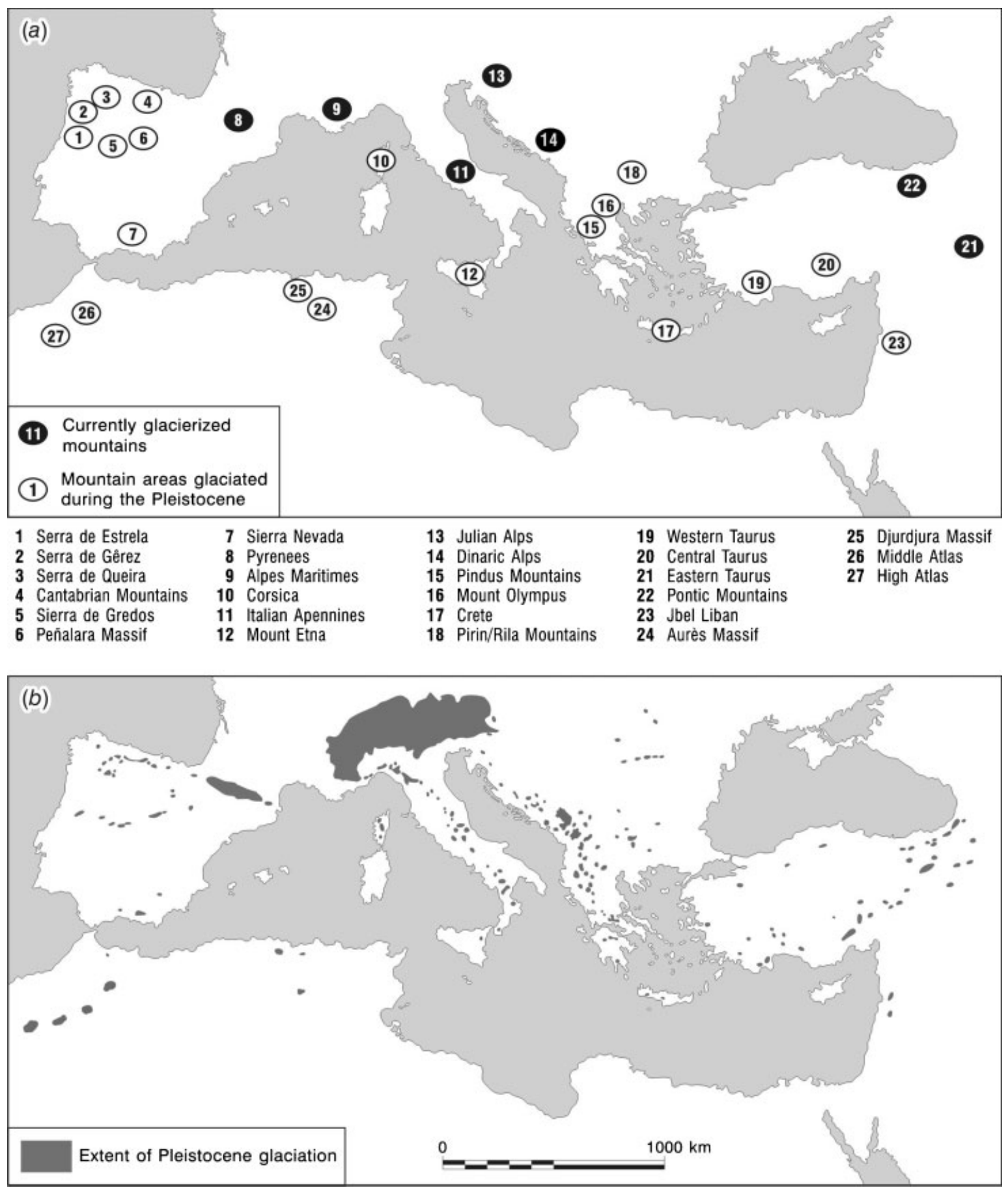

Figure 1 (a) Mountains of the Mediterranean currently glacierised and glaciated during the Pleistocene. (b) Extent of Pleistocene glaciation in the Mediterranean (after Messerli, 1967, and Hughes et al., 2006a). This map is schematic and, because of scale, does not intend to provide an accurate depiction of exact glacier sizes and locations

on moraine deposits at the El Portalet site (González-Sampériz et al., 2006) suggests that the glacier maximum in this area during the last cold stage also pre-dates the LGM at $18{ }^{14} \mathrm{C}$ ka BP (ca. 21 cal. ka BP) (Fig. 2). This is consistent with the findings elsewhere in the Pyrenees suggesting an early local last glacier maximum. A hiatus in the lacustrine sequence at $19.25 \pm 0.12$ ${ }^{14} \mathrm{C}$ ka BP is interpreted as an erosion surface caused by glacier readvance corresponding to the LGM. However, there is no direct evidence of glacier readvance at this time - other than the presence of a hiatus in the lacustrine sedimentary record represented by sharp changes in vegetation associations and very low sedimentation rates. All three features could have resulted from climatic deterioration in the absence of glacier advance, especially if conditions in the Mediterranean became drier around the time of the global LGM (cf. Pons and Reille, 1988; Allen et al., 1999; Fontugne et al., 1999; Tzedakis, 1999).

Other geochronological data are available for the Pyrenees in the form of optically stimulated luminescence (OSL) ages. Sancho et al. (2002) interpreted OSL ages from till deposits in the Cinca Valley as indicating that the maximum extent of Late Pleistocene glaciers in this area was reached at ca. $53.2 \pm 6.6 \mathrm{ka}$ (weighted average of two dates). This age is consistent with OSL ages of $58.1 \pm 3.2 \mathrm{ka}$ (weighted average of six dates) obtained from sediments within a large terraced fluvial aggradation located downstream of the glacial deposits well above the active channel, which Sancho et al. (2002) interpreted as being related to former glacier outwash. Peña et al. (2004) also applied OSL to date glaciofluvial deposits in 


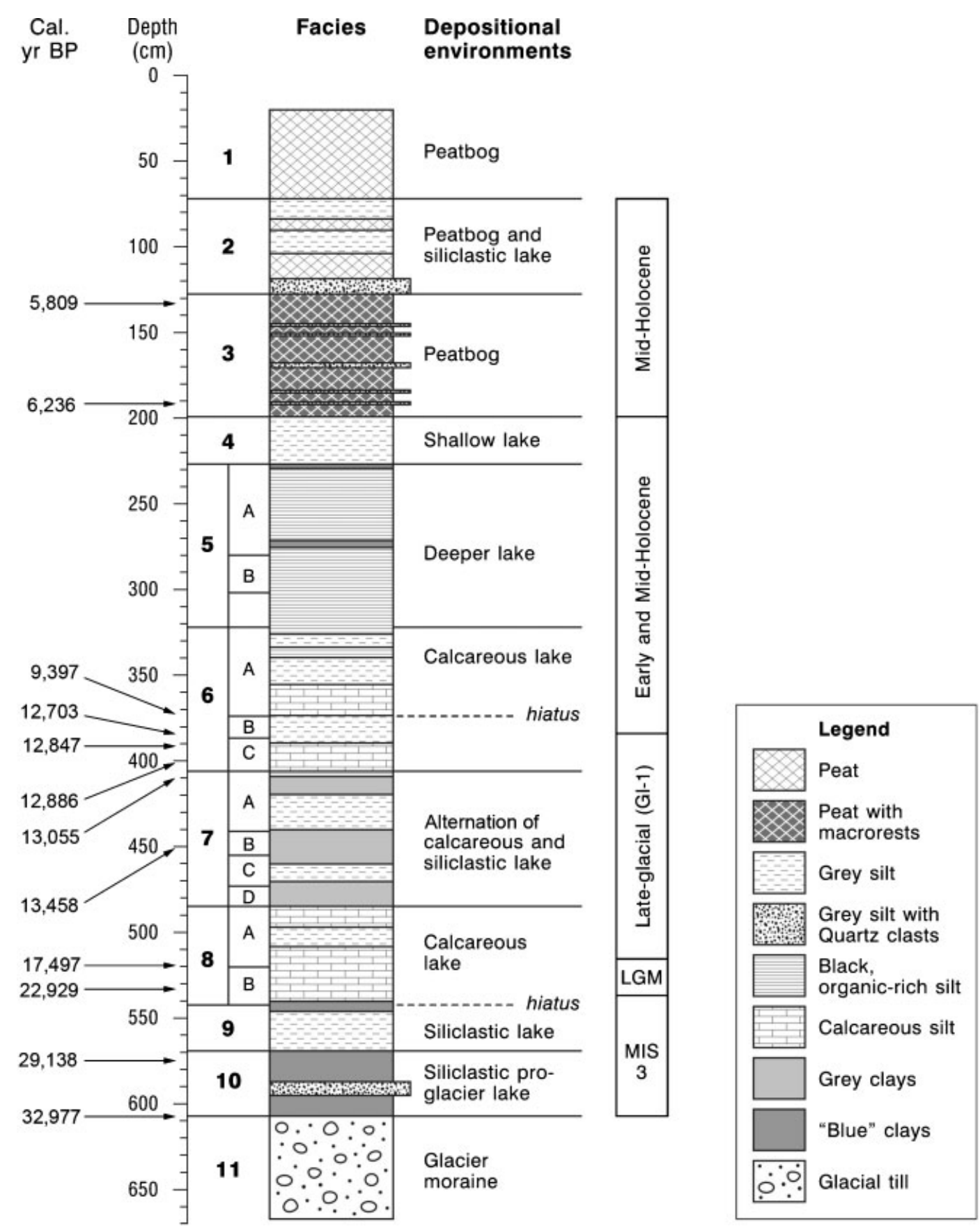

Figure 2 Lithological description of the El Portalet sequence in the upper part of the Gallego valley in the central-western Spanish Pyrenees, showing radiocarbon ages down the core. The El Portalet peat bog is located within a small cirque and is enclosed by moraines (González-Sampériz et al., 2006). The oldest radiocarbon dates provide minimum ages for the moraines. Redrawn with permission from Elsevier

the Gállego Valley to the west. They were able to differentiate between three phases of glacier advance using OSL, at ca. 155.8 ka (Sabiñánigo phase), 85 ka (Aurín phase) and 35.7 ka (Senegüe phase). The youngest phase of glaciation clearly predates the global LGM by nearly $15 \mathrm{ka}$ and provides some independent support for the radiocarbon-based dating frameworks from other glacial sequences in the Pyrenees.

Recent cosmogenic nuclide analyses appear to conflict with the dating frameworks that argue for an 'early' glacier maximum in the Pyrenees and suggest a local glacier maximum after 25 ka ago. Pallàs et al. (2007) presented $25{ }^{10}$ Be exposure analyses for granodioritic glacial erosion surfaces and boulders in the Upper Noguera Ribagorçana Valley in the south-central Pyrenees (Fig. 3). On the lowermost glacial units, the oldest exposure age was $21 \pm 4.4 \mathrm{ka}$ and was obtained from an erratic boulder. However, they also obtained a much younger
${ }^{10}$ Be exposure age of $6.6 \pm 1.4 \mathrm{ka}$ on the same stratigraphical unit,. Conversely, a ${ }^{10} \mathrm{Be}$ exposure age of $25.3 \pm 2.4 \mathrm{ka}$ has been obtained from some of the highest moraines (known as the 'Hospital moraines') in the Upper Noguera Ribagorçana Valley. Pallàs et al. (2007, p. 2954) argue that: 'Some ${ }^{10}$ Be dates are incoherent when compared with dates from the same moraine or dates from neighbouring sites. Such aberrant cases were avoided by withdrawing (1) one date (ART01) differing by more than two standard deviations with respect to the older dates from the same moraine, and (2) dates inconsistent with the geomorphologically based relative chronology. The minimum exposure age of each moraine was then deduced by calculating the error weighted mean of the remaining dates.' Despite these problems, which are common with cosmogenic exposure 'ages' and are discussed further below, the recent challenge to the idea of an early glacial maximum in the 

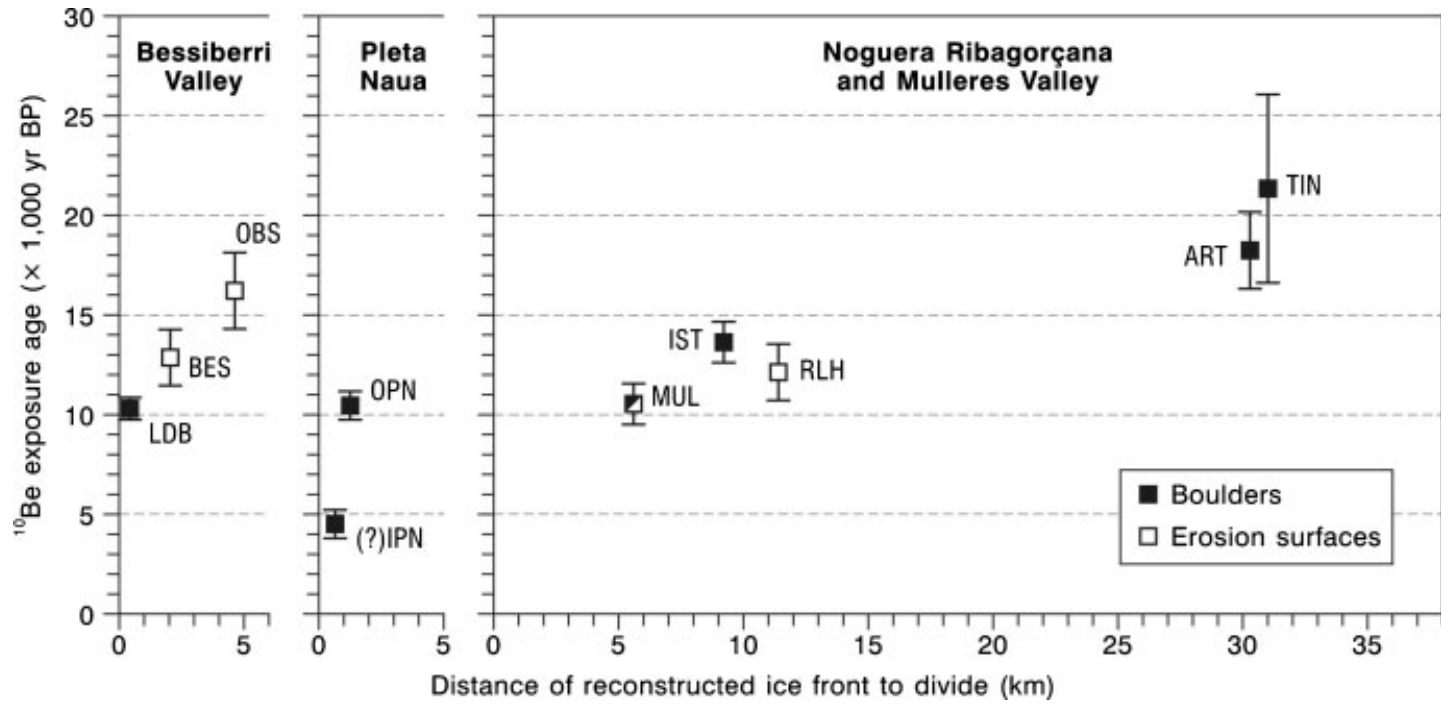

Figure 3 Time-distance diagram illustrating ${ }^{10}$ Be exposure ages against distance upvalley in the glaciated Noguera Ribagorçana and Mulleres valleys in the south-central Pyrenees (Pallàs et al., 2007). The Bessiberi and Pleta Naua valleys are situated in the upper catchment of the Noguera Ribagorçana valley. The ${ }^{10}$ Be dates appear to suggest that the exposure ages of the lowest moraines straddle the global last glacial maximum (LGM) at ca. $21 \mathrm{ka}$ (samples ART and TIN). Redrawn with permission from Elsevier

Pyrenees by Pallàs et al. (2007) is certainly intriguing and future progress may hinge on the parallel application of different dating techniques to test the various hypotheses.

\section{The Maritime Alps: France and Italy}

The Maritime Alps of southern France and western Italy currently support 15 small glaciers (Federici and Papparlardo, 1995). These glaciers are the southernmost of the Alpine chain and some are situated less than $50 \mathrm{~km}$ from the Mediterranean coast (Fig. 1). During the last cold stage (Würmian Stage), the Maritime Alps were covered by ice that was contiguous with the main Alpine ice sheet to the north, extending over an area of ca. $126000 \mathrm{~km}^{2}$ (Ehlers, 1996). Lacustrine sediments at the glacial Lac Long Inférieur $(2090 \mathrm{~m}$ a.s.I.) indicate that deglaciation had begun by $14.19 \pm 0.13{ }^{14} \mathrm{C}$ ka BP (Ponel et al., 2001).

The lowest frontal and lateral moraines in the Gesso Valley have recently been dated using ${ }^{10} \mathrm{Be}$ nuclide analysis (Granger et al., 2006). Boulders sampled on two separate moraine crests gave mean ${ }^{10} \mathrm{Be}$ cosmogenic ages of $16.3 \pm 0.88$ and $18.798 \pm 0.973 \mathrm{ka}$. Granger et al. (2006) argued that these two moraines represent the inner and outer moraine crests of the same glacial event. The older maximum age of the Gesso glacier is broadly consistent with the Alps further north, where the northern lobe of the Rhône glacier reached its maximum extension between ca. 21 and $19.1 \mathrm{ka}$ ago around the time of the global LGM (Ivy-Ochs et al., 2004).

Later glacier advances at higher elevations in the Gesso valley have also now been dated using ${ }^{10} \mathrm{Be}$ exposure age dating (Federici et al., 2008). Four boulder samples from the Piano del Praiet frontal moraine gave a weighted mean age of $11.34 \pm 0.37 \mathrm{ka}$. Federici et al. (2008) suggest that the frontal moraine correlates with the Egesen stadial of the Alps (Younger Dryas) and they argue that this suggests a synchroneity of the Egesen deglaciation across the European Alps. Comparison with other areas of the European Alps suggests that the Maritime Alps experienced wet and cold climatic conditions during the Younger Dryas - in common with the Pindus Mountains of Greece further to the east (Hughes et al., 2006c).

\section{The Italian Apennines}

In the Gran Sasso massif of the Central Apennines (Fig. 1), Giraudi and Frezzotti (1997) mapped a series of moraines and rock glaciers and demonstrated that the maximum glacier extent occurred prior to $22.68 \pm 0.63{ }^{14} \mathrm{C}$ ka BP $(27230 \pm$ 868 cal. ka BP) in the Campo Imperatore valley (Fig. 4). This indicates that the valley glacier in this area reached its maximum prior to the global LGM. A series of recessional moraines and rock glaciers are thought to correspond to periods of glacier stabilisation or readvance between 20 and $10{ }^{14} \mathrm{C}$ ka $\mathrm{BP}$, including during the Mount Aquila stadial, which is correlated with the Younger Dryas Chronozone (Fig. 4). Little geochronological evidence exists elsewhere in this region and many papers assume that moraine assemblages formed during the last cold stage (Würmian) (e.g. Boenzi and Palmentola, 1997).

\section{Montenegro}

By Mediterranean standards, Montenegro was host to very large glaciers during the Pleistocene and included ice caps which submerged large areas of the central uplands (Liedtke, 1962). Extensive glaciers also developed on the coastal mountains, such as Orjen (1894 m a.s.I.) (Sawicki, 1911; Menkovic et al., 2004). Recent $U$-series dates from secondary calcites within moraines from sites across Montenegro indicate that the largest glaciations occurred during the Middle Pleistocene cold stages (Hughes and Woodward, unpublished data). At the head of the Karlica valley in the Durmitor massif, there is a modern glacier with a suite of large frontal moraines dated using lichenometry to the late 19th and early 20th centuries (Hughes, 2007). Around $1 \mathrm{~km}$ down-valley of this small glacier, just above the Struga pass between the peaks of Međed (2287 $\mathrm{m}$ a.s.I.) and Savin kuk (2313 $\mathrm{m}$ a.s.I.), there are clear end moraines containing secondary calcites. These have recently been dated using $U$-series to $10605 \pm 193 \quad\left({ }^{230} \mathrm{Th} /{ }^{232} \mathrm{Th}=99.3\right)$ and $9575 \pm 836\left({ }^{230} \mathrm{Th} /{ }^{232} \mathrm{Th}=49.9\right)$ a $($ Fig. 5). These dates are significant because they show that Holocene glacier extent in 


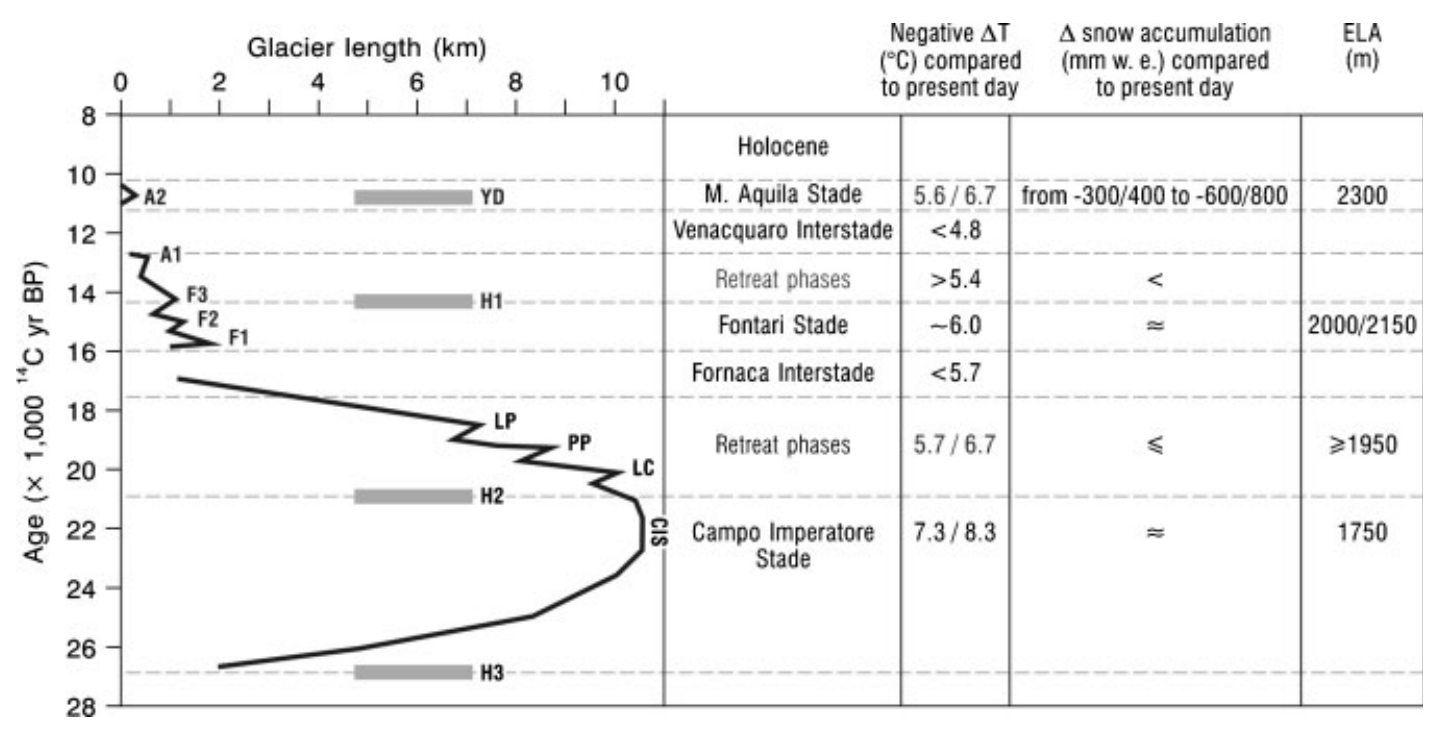

Figure 4 Time-distance diagram illustrating glacial phases in the Campo Imperatore valley of the Gran Sasso massif, Italian Apennines (YD, Younger Dryas; H1, H2, H3, Heinrich events 1, 2, 3; F1, F2, F3, Fontari stadial advances; A1, A2, Aquila stadial advances; CIS, Campo Imperatore stadial) (Giraudi and Frezzotti, 1997). Redrawn with permission from Elsevier

this valley must have been restricted in size and situated close to the modern and 19th-century glacier limits. Furthermore, the $\mathrm{U}$-series ages, which provide minimum ages for the moraines, suggest that the last time a valley glacier extended as far as the Karlica Member moraines was during the Younger Dryas (12.911.5 cal. ka BP).

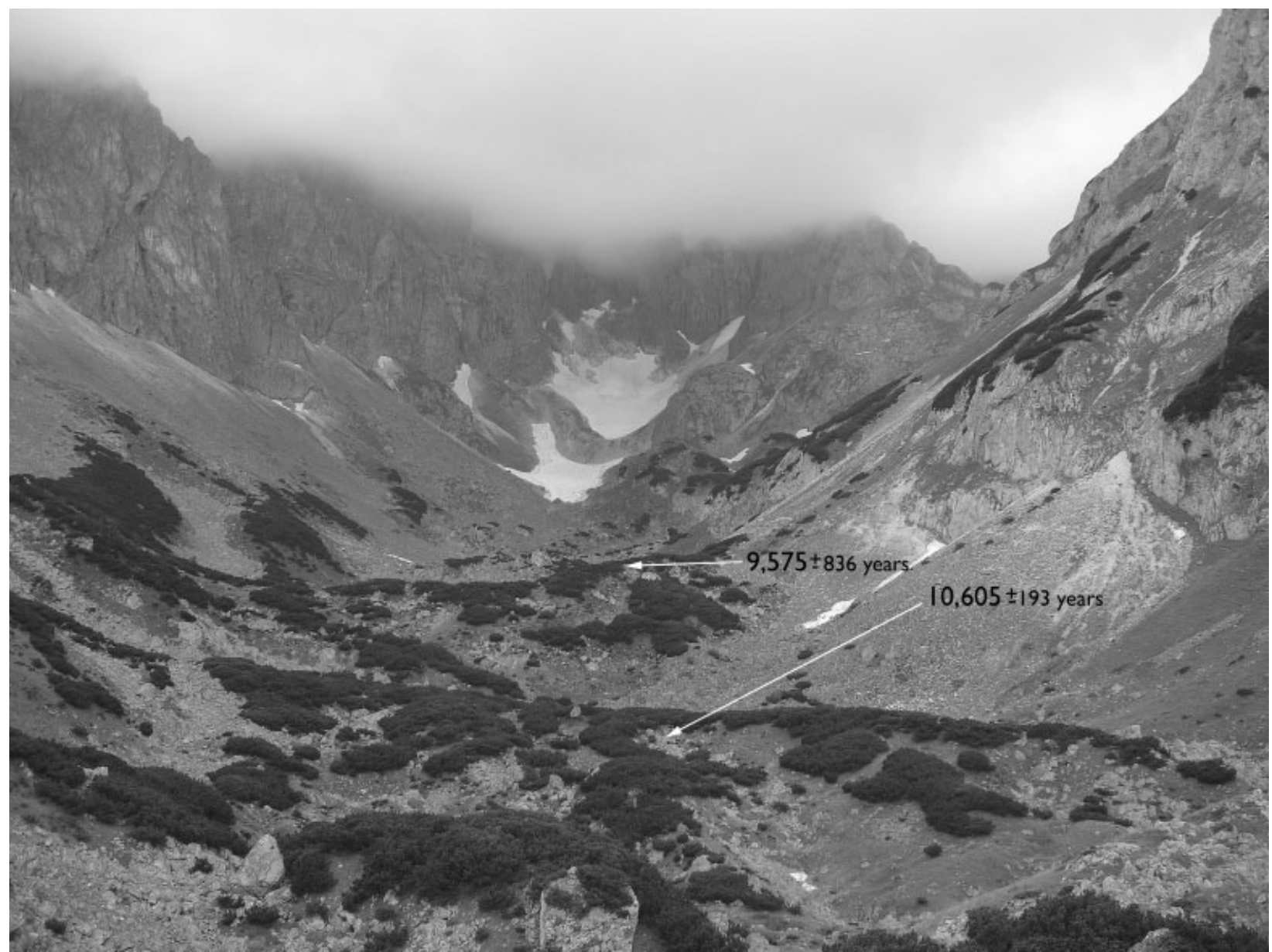

Figure 5 Photograph showing moraines in the Karlica Valley in the Durmitor Massif, Montenegro. Secondary calcites within these moraines have been dated using $U$-series and provide a minimum age for the host moraines. A modern glacier - the Debeli Namet - is present at the head of the valley (Hughes, 2007). These U-series dates are important because they demonstrate that the valley moraines are likely to be Late Pleistocene in age - possibly correlating with the Younger Dryas. Moraines downvalley of these moraines have yielded progressively older U-series ages, with the lowest moraines in this area dating to the Middle Pleistocene 


\section{Greece}

Glacial deposits are widespread in the Pindus Mountains of Greece, from Taygetos (2404 m a.s.I.) in the south to Grammos (2520 m a.s.I.) in the north (Hagedorn, 1969; Mastronuzzi et al., 1994; Woodward et al., 2004) and Olympus in the east (Smith et al., 1997). The Late Pleistocene (Pindus chronostratigraphy: Tymphian Stage) glaciers in the Pindus Mountains were much smaller than their Middle Pleistocene counterparts (Skamnellian and Vlasian Stages) (Fig. 6). The separation of Late and Middle Pleistocene glacial units has been achieved by detailed mapping and by applying $U$-series methods to date secondary calcite cements in glacial deposits on Mount Tymphi (Woodward et al., 2004; Hughes et al., 2006b). However, radiometric ages have only been obtained from the Middle Pleistocene moraines because no secondary calcites were found in younger moraines. Nevertheless, some insights into the timing of Late Pleistocene glaciation can be inferred from radiometric dates obtained from fluvial sediments deposited by the Voidomatis River, which drains the southern slopes of Mount Tymphi.

A major alluvial unit with a glacially derived fine-grained matrix formed downstream of the largest Tymphian Stage glaciers on Mount Tymphi. This unit was dated to ca. 28.2$24.3 \mathrm{ka}$ on the basis of a thermoluminescence date, three electron spin resonance dates and two U-series dates (Lewin et al., 1991; Hamlin et al., 2000; Woodward et al., 2008). The sand and silt matrix of this unit is dominated by limestone-rich

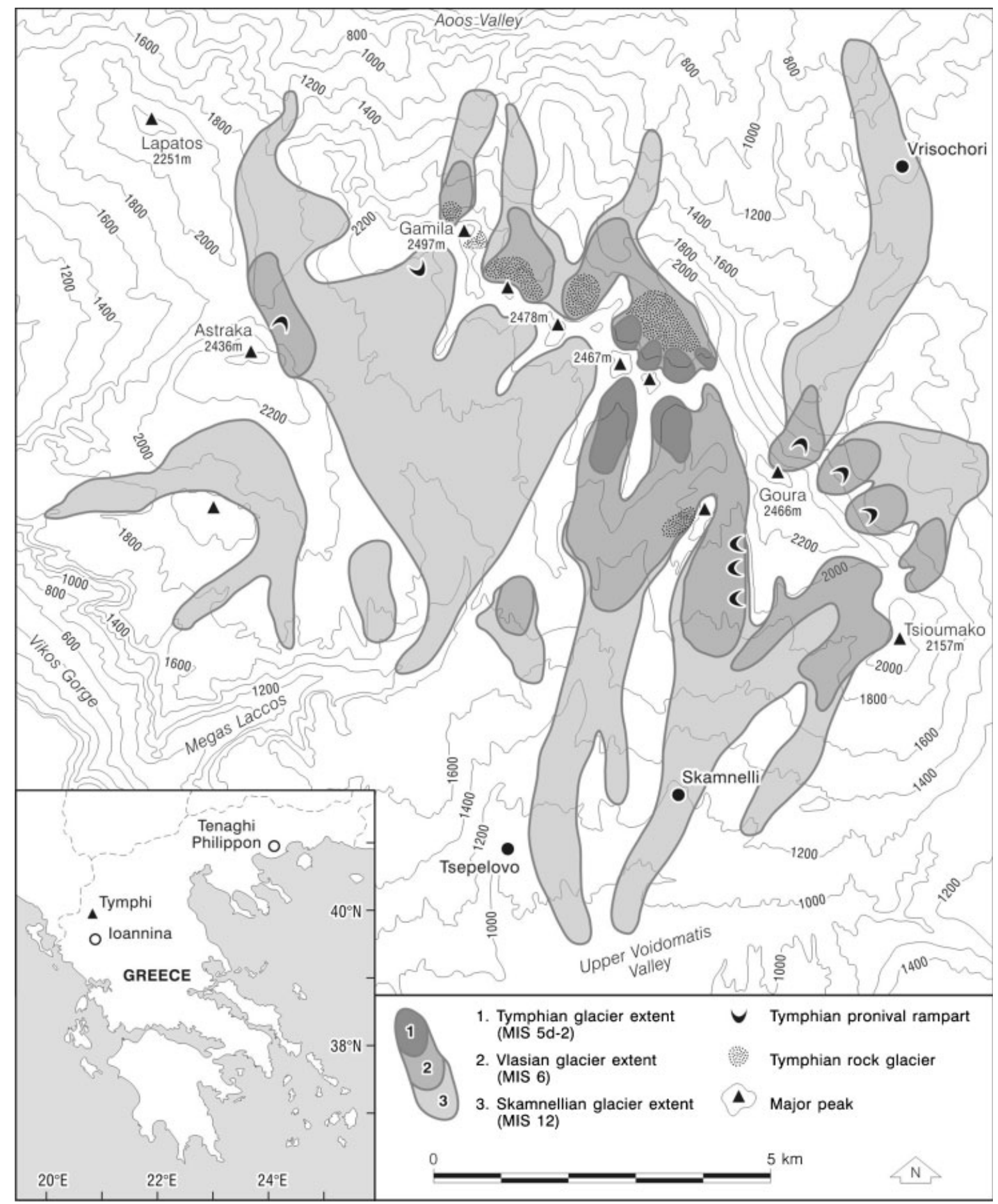

Figure 6 Pleistocene glacier extent on Mount Tymphi in the Pindus Mountains, northwest Greece (based on Hughes et al., 2006b) 
fines which are derived from glacial erosion in the catchment headwaters (Lewin et al., 1991; Woodward et al., 1992). The age of these fluvial sediments shows that this glacial activity occurred several thousand years prior to the global LGM. Meltwater erosion of older Middle Pleistocene glacial deposits may have also provided a significant contribution to the sediment load of the Late Pleistocene Voidomatis. In total, three alluvial units of Tymphian Stage age, with lithological characteristics that indicate aggradation in response to increased sediment supply from upper catchment glaciation, have been identified in the Voidmatis basin - at ca. 28.2$24.3 \mathrm{ka} ; 53 \pm 4 \mathrm{ka}$; and $80 \pm 7 \mathrm{ka}$ (Lewin et al., 1991; Hamlin et al., 2000; Woodward et al., 2008) (Fig. 8).

\section{Turkey}

Until recently there were no dates for glacial deposits and landforms in Turkey (Çiner, 2004). However, recent projects have published cosmogenic nuclide results from several areas. In the Kaçkar Mountains bordering the Black Sea (Fig. 1), Akçar et al. (2007) have presented ${ }^{10} \mathrm{Be}$ ages from granitic surfaces in the Kavron Valley on the southern slopes of the highest peak, Kaçkar Dağı (3932 m a.s.I.) (Fig. 7). The Kavron Valley glacier advance began at least $26 \pm 1.2 \mathrm{ka}$ ago and continued until
$18.3 \pm 0.9 \mathrm{ka}$ ago. After this time the glacier retreated and by $15.5 \pm 0.7 \mathrm{ka}$ the main valley became ice-free with glaciers restricted to tributary cirques. A later glacier advance took place between $13 \pm 0.8$ and $11.5 \pm 0.8 \mathrm{ka}$ ago. A similar situation has been reported from a northward-draining valley of Mount Verçenik (3907 m a.s.I.), the second highest peak in the Kaçkar Mountains. Here, a valley glacier advanced before $26.1 \pm 1.2 \mathrm{ka}$ and continued to advance until $18.8 \pm 1 \mathrm{ka}$ ago. According to Akçar et al. (2008), the Verçenik glacier collapsed rapidly and after $17.7 \pm 0.8 \mathrm{ka}$ ago the main valley was ice-free with only five small glaciers in tributary valleys. Among these, the Hemşin glacier had completed its retreat by ca. $15.7 \pm 0.8 \mathrm{ka}$ ago. This was followed by a Lateglacial advance, identified on the basis of glacial erosion features (Akçar et al., 2008).

In western Turkey, in the north-facing valleys of Mount Sandıras (2295 $\mathrm{m}$ a.s.I.), Late Pleistocene glaciers extended to ca. $1.5 \mathrm{~km}$ in length and terminated at an altitude of ca. $1900 \mathrm{~m}$ a.s.l. Sarıkaya et al. (2008) have utilised in situ cosmogenic ${ }^{36} \mathrm{Cl}$ to ascertain the exposure age of boulders on moraine surfaces in these valleys and found that the last local glacier maximum occurred at approximately $20.4 \pm 1.3 \mathrm{ka}$. In this valley, glacier retreat was interrupted by readvances at ca. $19600 \pm 1600$ and $16.2 \pm 0.5 \mathrm{ka}$. Glacier modelling suggest that temperatures during the last glacier maximum on Mount Sandıras were $8.5-11.5^{\circ} \mathrm{C}$ lower than modern values and that

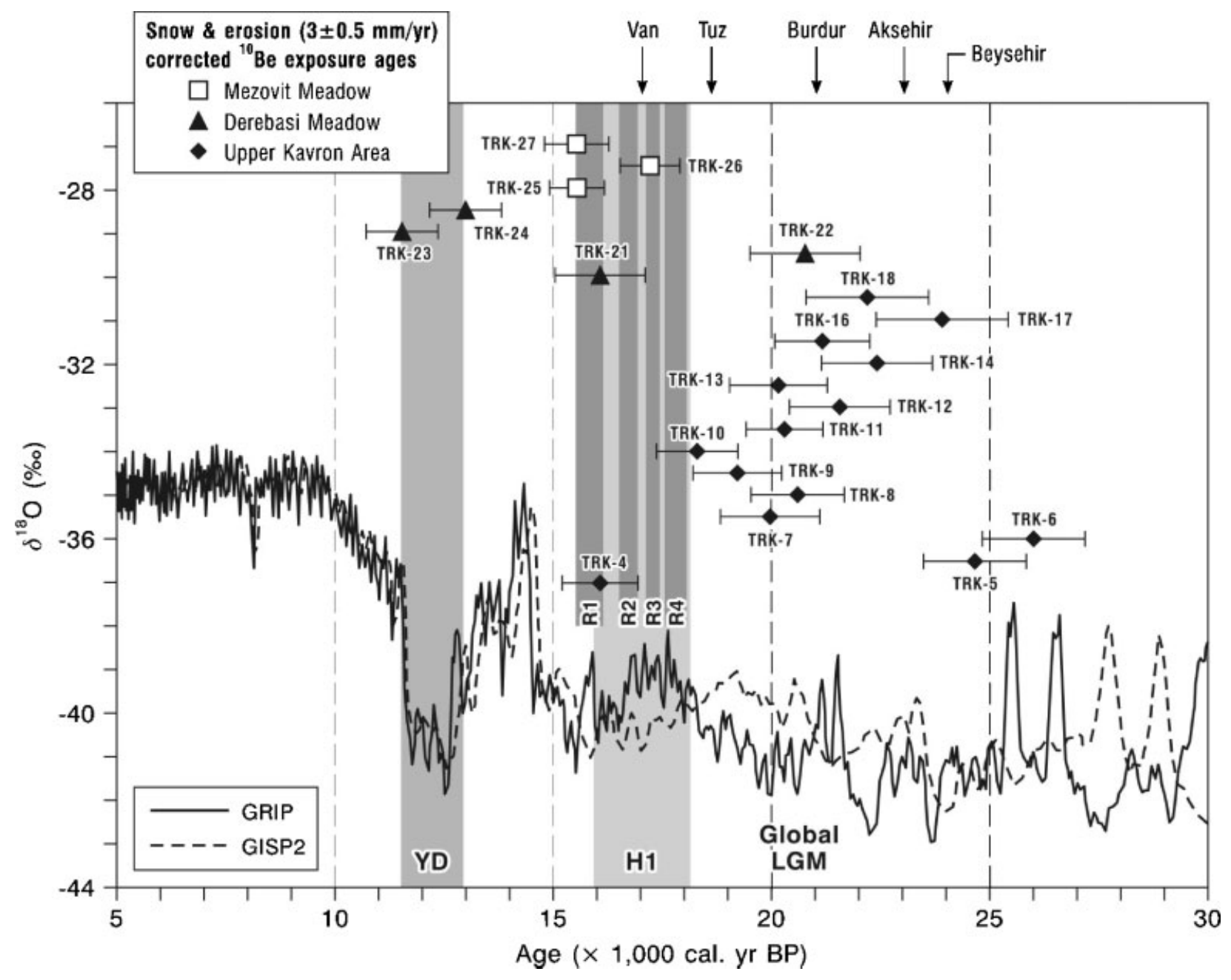

Figure 7 Erosion-corrected ${ }^{10}$ Be exposure ages from the Kavron Valley, in the Kaçkar Mountains, Turkey (Akçar et al., 2007). The arrows at the top of the diagram illustrate the timing of major regression in closed lakes in Turkey. The labels R1 to R4 and associated grey shading indicate four major red layers deposited between 18 and 15.5 ka in the Black Sea. H1, Heinrich 1; YD, Younger Dryas; LGM, global Last Glacial Maximum. Redrawn and slightly modified with permission from Elsevier 


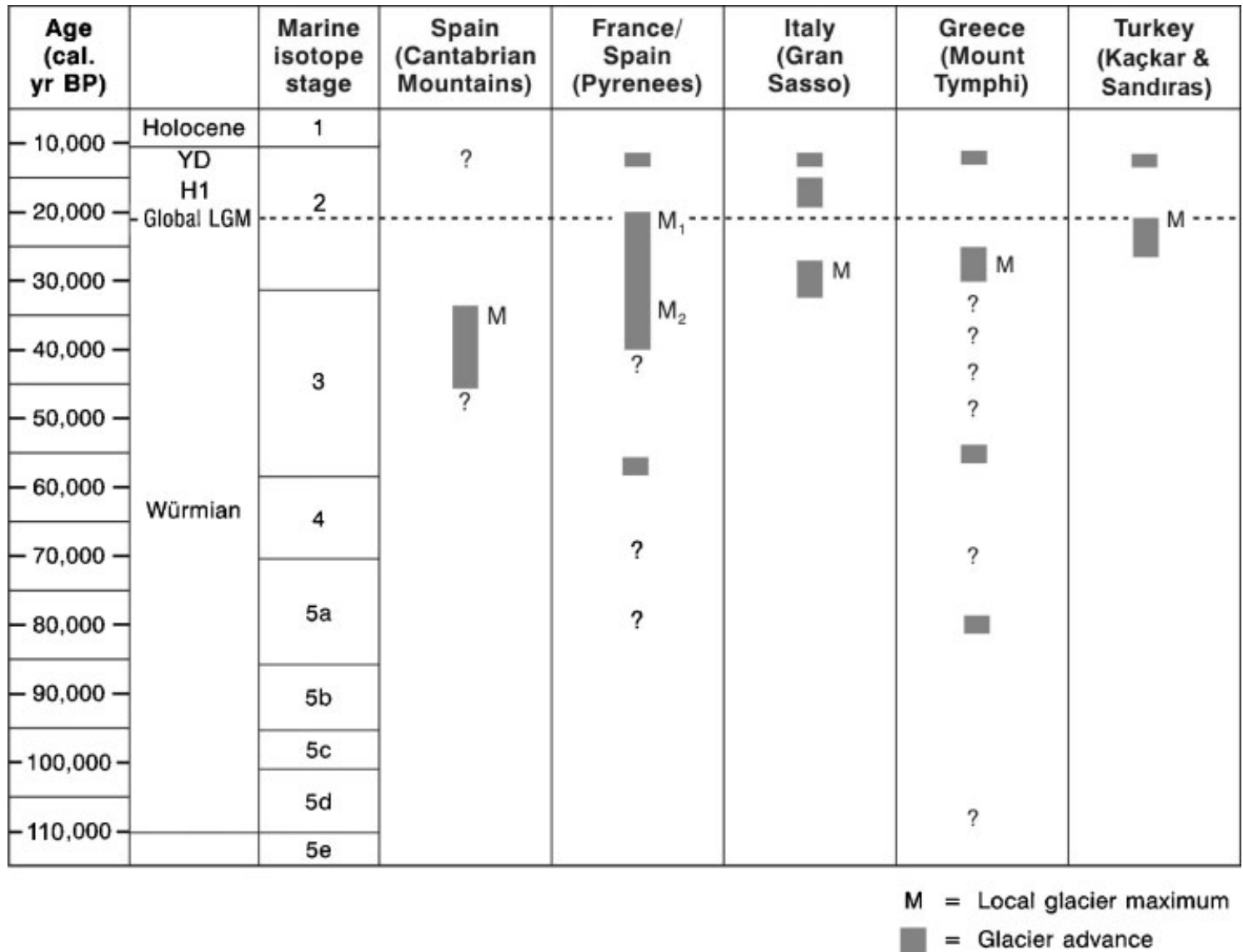

Figure 8 Timing of glacier advances and glacier maxima in the mountains of the Mediterranean. This diagram is based on fully published data from the Cantabrian Mountains (Jiménez-Sanchez and Farias, 2002), the Pyrenees (e.g. García-Ruiz et al., 2003; González-Sampériz et al., 2006; Pallàs et al., 2007), the Italian Apennines (Giraudi and Frezzotti, 1997), Greece (Hughes et al., 2006d; Woodward et al., 2008) and Turkey (Akçar et al., 2007, 2008; Sarıkaya et al., 2008) and excludes data presented only in published abstracts (e.g. Granger et al., 2006; Palacios et al., 2007). M1, based on ${ }^{10}$ Be exposure dating (Pallàs et al., 2007); $\mathrm{M}_{2}$, based on ${ }^{14} \mathrm{C}$ and OSL dating (García-Ruiz et al., 2003; González-Sampériz et al., 2006; Peña et al., 2004). YD, Younger Dryas; H1, Heinrich 1. Question marks indicate tentative evidence for possible or potential glacier advances

precipitation was nearly double that of today (Sarıkaya et al., 2008).

\section{Problems with the glacial geochronologies}

A summary of the timing of glacial advances and maxima in different areas across the Mediterranean is provided in Fig. 8. Based on a range of geochronological data, there is evidence in the glacial records from the Pindus Mountains, the Italian Apennines and the Pyrenees for local glacial maxima preceding the LGM at ca. $18{ }^{14} \mathrm{C}$ ka BP/21 cal. ka BP by at least several thousand years. An early glacier maximum has also been reported from the Italian Alps. Recent radiocarbon dates from boreholes in the Tagliamento basin in the Italian Alps suggest a complex situation with an earlier glacier maximum between 26.5 and 23 cal. ka BP, which was followed by a later readvance between 24 and 21 cal. ka BP (Monegato et al., 2007). However, all of the studies that have used in situ cosmogenic analyses to provide exposure ages for glacial landforms further to the south in the Mediterranean mountains (central Spain, Pyrenees, Maritime Alps, west and east Turkey) have yielded results showing a close correspondence between the local glacier maxima and the LGM. This body of new information is based on at least five separate studies. The results of these Mediterranean studies are consistent with cosmogenic exposure ages from boulders on the northern European Alpine foreland where the northern lobe of the Rhône glacier reached a maximum between ca. 21 and 19.1 ka (e.g. Ivy-Ochs et al., 2004).

A key problem for the development of robust dating frameworks for glacial sequences is the analysis and interpretation of the geochronological datasets. Many of the studies that employ cosmogenic nuclide analyses to derive exposure ages rely on statistical interpretation of the results. For example, in Pallàs et al. (2007), Akçar et al. (2008) and Sarıkaya et al. (2008), there are outlying ages pre-dating the LGM by several thousand years. Such outliers are to be expected with this approach and they are generally explained as the result of cosmogenic nuclide inheritance. A similar problem exists with young outliers, which may result from landform or boulder surfaces that have been exhumed or a where a boulder has toppled some time after deposition on a moraine surface.

Of course, other dating techniques have problems of interpretation too (Walker, 2005). Many of the radiocarbon dates used to support ideas of an early glacier maximum in the Pyrenees have been criticised by Pallàs et al. (2007). They cite problems such as hard water error in areas dominated by carbonate lithologies - which can produce ages which are much older than is really the case; the reworking or contamination of pollen concentrates used for some radiocarbon dates; and the uncertain stratigraphical context of some radiocarbon dates. 
However, there is also the potential problem of 'old' OSL ages from till and glaciofluvial sediments in the Pyrenees (Sancho et al., 2002; Peña et al., 2004). Pallàs et al. (2007, p. 2959) have argued that: 'A simple way of reconciling the relatively young ages of the glacial features [based on ${ }^{10} \mathrm{Be}$ analyses] with the older ${ }^{14} \mathrm{C}$ data $(\geq 30 \mathrm{ka})$ and the recently published OSL ages (ca. 85-35 OSL ka from glacial and glaciofluvial sediments in the Cinca and Gallego valleys), if confirmed, would be to consider that pleniglacial conditions could have taken place during a longer period than generally assumed. Hence, the data available suggest a long Last Pleniglacial (>30-20 ka ago), which would include several glacier fluctuations recorded irregularly in different valleys, with a last major glacier readvance taking place around the LGM.' This explanation is certainly plausible and has been suggested elsewhere. For example, in the Pindus Mountains of Greece, Hughes et al. (2006d) suggested that at least 10 intervals were characterised by climatic conditions favourable for glacier formation during the last cold stage.

Ideally, multiple geochronological techniques should be applied whenever possible. This is especially the case for the Pyrenees, where ${ }^{10} \mathrm{Be}$ exposure ages conflict with radiocarbon and OSL dates from the same area (Fig. 8). Resource constraints often hamper attempts to develop multiple geochronologies in glaciated areas, as does the availability of suitable samples.

\section{Mediterranean glacial environments during the last glacial cycle}

The various glacial geochronologies from around the Mediterranean appear to produce two models of glaciation for the last cold stage: one where mountain glaciers reached their maximum extent before the global LGM and one where their maximum advance was broadly synchronous with the global LGM. It is instructive to view these findings within the wider palaeoclimatic context as each scenario has important implications for the transfer of precipitation-bearing depressions across the Mediterranean basin during the last cold stage.

It is clear that temperate tree populations were severely constricted across the Mediterranean region around the time of the global LGM because of cold and dry conditions (Pons and Reille, 1988; Allen et al., 1999; Fontugne et al., 1999; Tzedakis, 1999). In order for glaciers to advance at this time in the Mediterranean mountains, extremely large reductions in summer temperature compared with today would be needed to offset the reduced snow accumulation caused by the dry climate. This would have also been true during Heinrich events, which are also associated with cold and dry conditions, resulting in major reductions in tree populations in the Mediterranean (Tzedakis et al., 2002).

Hughes et al. (2006d) suggested that palaeoglaciers in Greece are likely to have retreated during the extremes of both stadials (including Heinrich events) and interstadials and advanced during more intermediate phases of the last cold stage, when climate was sufficiently wet and cold for a positive glacier mass balance. Examples of intermediate phases of climate where these glacier-climate conditions may have occurred have been identified from the pollen record at loannina and are shown as Type B in Fig. 9. Glacier-climate reconstructions for the last local glacier maximum in northern Greece indicate that climate at the equilibrium line altitude (ELA) was characterised by annual precipitation of $2300 \pm 300 \mathrm{~mm}$ and mean summer temperatures of $4.9^{\circ} \mathrm{C}-$ a situation analogous with modern-day maritime Norwegian glaciers (Hughes et al., 2006d). This climatic reconstruction for the last local glacial maximum in Greece is consistent with the glacial evidence in the Italian Apennines (Giraudi and Frezzotti, 1997) and western Turkey (Sarıkaya et al., 2008) as shown below.

The last occurrence of potentially wet and cold conditions before the most severe and driest phase of the last cold stage was during the interval between ca. 30 and $25 \mathrm{ka}$ ago (Fig. 9). However, theoretically favourable conditions for significant glacier formation can be recognised for at least nine other intervals within the last cold stage: the earliest being between ca. 111000 and 105000 , corresponding to Stadial 1 in the loannina pollen record and MIS $5 d$ (cf. Tzedakis et al., 2002); and the last between ca. 15 and $10{ }^{14} \mathrm{C}$ ka BP, during the Lateglacial (cf. Lawson et al., 2004). It is likely that Mediterranean glaciers waxed and waned throughout the last cold stage in response to climate change, but only the most extensive moraines have been preserved in many valleys. In fact, in some basins, the fluvial record downstream may provide a more detailed record of glacier activity for the last cold stage than the glacial geomorphological record itself (Hughes et al., 2006d; Woodward et al., 2008).

In the Italian Apennines, conditions were very cold and wet at the time of the local glacier maximum, with snowfall at the ELA similar to modern values (Giraudi and Frezzotti, 1997). As in Greece, the last local glacial maximum in the Italian Apennines appears to pre-date the most severe phase of climate represented in the pollen record at Monticchio, a long lacustrine sequence in southern Italy, when the lowest arboreal pollen abundances occurred between 25.9 and $14.3 \mathrm{cal}$. ka BP (22.35-12.5 ${ }^{14} \mathrm{C}$ ka BP) (Allen et al., 1999, 2000).

In Turkey, two glacial records with similar geochronologies have yielded very different palaeoenvironmental interpretations. In the Kaçkar Mountains, at the easternmost fringe of Mediterranean climatic influence, Akçar et al. (2007, 2008) have argued that the advance of glaciers was paralleled by the almost complete absence of trees in central Anatolia during Pleniglacial to Lateglacial times (Fontugne et al., 1999). However, this also coincided with a period of high lake levels in Turkey close to the global LGM (Kuzucuoğlu and Roberts, 1998). This apparent conflict has arisen elsewhere in Mediterranean lacustrine records (Prentice et al., 1992; Tzedakis, 2007). In Turkey, the combination of cold steppe vegetation and high lake levels has been explained by reduced evaporation and evapotranspiration, enhanced by higher catchment runoff coefficients (Kuzucuoğlu and Roberts, 1998). Akçar et al. $(2007,2008)$ argue for glacier advance with arid conditions and very low temperatures at the last local glacier maximum in this region. However, in the mountains of western Turkey, Sarıkaya et al. (2008) used a glacier-climate model to argue that the local glacier maximum in this area, which was reached at around the same time as that in the Kaçkar Mountains, occurred under a wet and cold climate with nearly double the precipitation of today. Further work is necessary to understand the relationship between glaciers and climate across Turkey and Akçar et al. (2007) themselves suggest that detailed mapping and regional reconstructions of former ice extent are needed to understand glacier-climate dynamics in these mountains. If the glacier-climate reconstructions of Sarıkaya et al. (2008) are correct, this has major implications for the interpretation of cold steppe vegetation assemblages in pollen record in lacustrine sequences across the Mediterranean.

Hughes et al. (2006a) argued that the small glaciers of the Mediterranean mountains would have responded rapidly to millennial-scale climate change, in contrast to the extensive ice sheets that covered the Alps and northern Europe. 


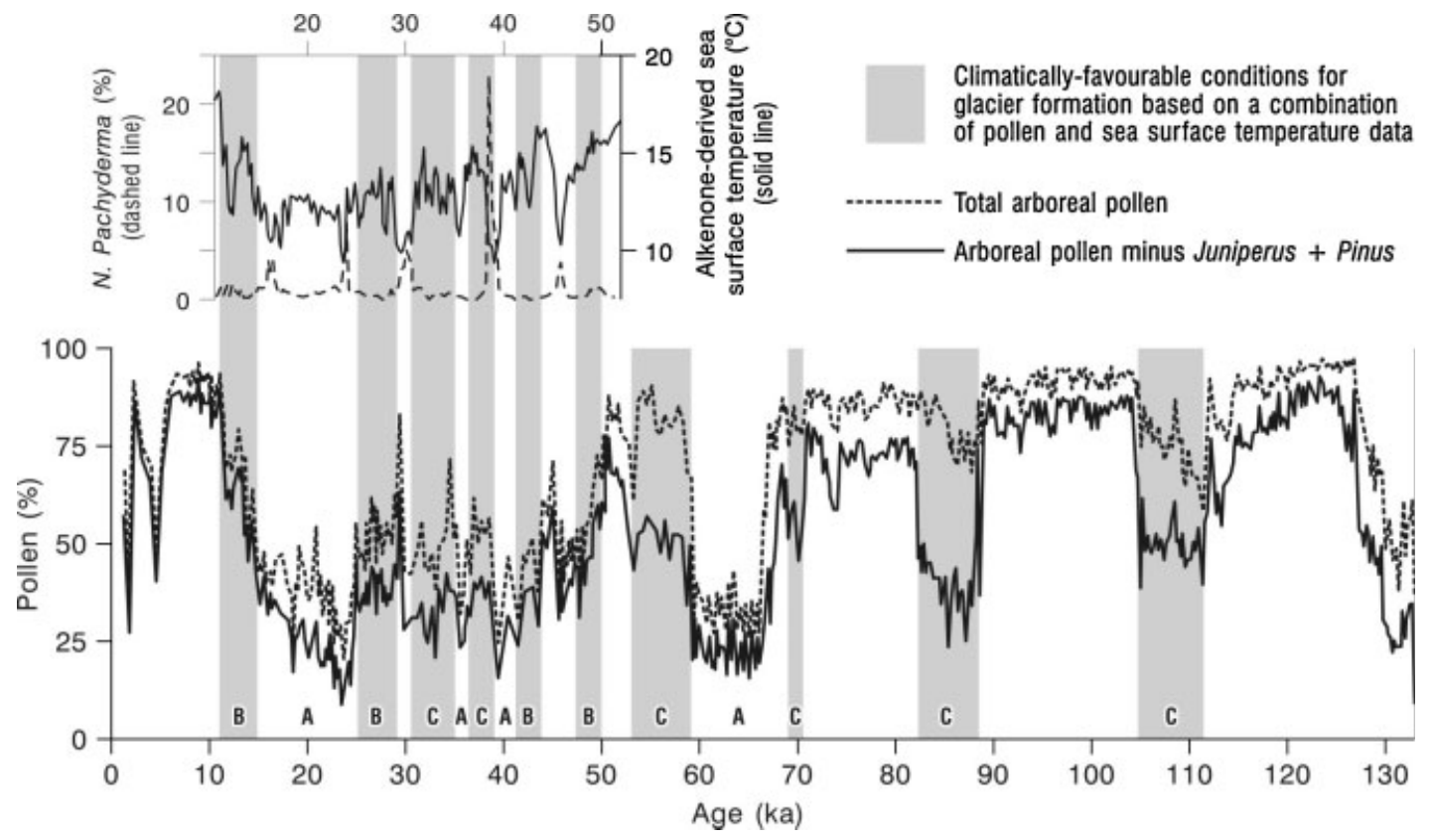

Figure 9 Summary pollen percentage curves from the Ioannina I284 sequence in northwestern Greece, spanning the last glacial cycle. Potential intervals suitable for glacier formation are indicated by letters A: major stadials characterised by low arboreal pollen, both including and excluding Pinus and Juniperus; B: intermediate phases between the apices of major stadials and interstadials; C: intervals characterised by large differences between total arboreal pollen frequencies and arboreal pollen frequencies, excluding Pinus and Juniperus. All other intervals represent major interstadials or interglacials. Both B and C types - the more favourable conditions for glaciation - are highlighted by shading. The upper graph depicts variations in the percentage of Neogloboquadrina pachyderma (sinstral) and alkenone-derived sea-surface temperatures in marine core MD95-2043 from the Alboran Sea, in the western Mediterranean (adapted from data in Cacho et al., 1999, and Tzedakis et al., 2002). Redrawn from an original figure in Hughes et al. (2006d) with permission from Elsevier

Consequently, the Mediterranean glaciers are likely to have advanced and retreated much more quickly and reached their maximum extent in the last cold stage before the large ice sheets. The potentially rapid response of mountain glaciers to the increased aridity in southern Europe around the time of the global LGM may explain the evidence for an early glacial maximum in the mountains of this area. This situation applied not only in the Mediterranean mountains but also in the locally glaciated mountain areas of Europe such as the Vosges (Seret et al., 1990) and the Massif Central (Etlicher and De Goer de Hervé, 1988), where glacial geochronologies based on radiocarbon dating indicate local glacier maxima prior to $30{ }^{14} \mathrm{C}$ ka BP.

A growing number of studies using cosmogenic nuclide analyses point to local glacier maxima in the Mediterranean mountains close to the global LGM at ca. $21 \mathrm{ka}$ ago. These include cosmogenic exposure geochronologies for glacial sequences in the Sierra de Gredos of Spain, the Pyrenees, the Maritime Alps and both the western and eastern mountains of Turkey. It is possible that moisture availability to nourish glacier development could have been facilitated by a southerly track of Atlantic depressions through the Mediterranean basin during MIS 2 (Florineth and Schlüchter, 2000). This is plausible but would appear to conflict with the palaeoecological data from long lacustrine records and the established view of a cold and dry Mediterranean climate around the time of the LGM (Tzedakis, 2007). Reduced precipitation during Heinrich events is also likely to have restricted glacier growth. As noted earlier, the palaeoglacier record in western Turkey appears to show evidence of cold and wet conditions at the LGM (Sarıkaya et al., 2008).

Given the context of high-amplitude millennial-scale climate change known to have occurred in the Mediterranean region during the last cold stage, it is likely that Mediterranean mountain glaciers oscillated in response to these climate signals, as noted earlier. Dynamic modelling of glacier-climate response over the last cold stage may help provide some insight into the oscillations of the Mediterranean glaciers to millennialscale climate change - especially with respect to major collapses in precipitation that are thought to have occurred during intervals coinciding with Heinrich events in the North Atlantic (Allen et al., 1999; Tzedakis et al., 2002). Glacial landforms such as moraines reflect 'events' in the stratigraphical record and it is possible that local and regional climatic variations resulted in variability in the timings of local glacier maxima in the mountains. It is therefore not surprising, perhaps, that there appear to be conflicts between different records of environmental change. Tzedakis (2007) argued that higherresolution analyses and improved chronologies have led to a revised framework of geographically coherent environmental changes in the Mediterranean region during the last cold stage. Of course, glacial sedimentary records cannot rival the lacustrine or speleothem records in terms of temporal resolution. Nevertheless, it can be argued that glacial 'events' such as local glacier maxima can provide some of the most reliable palaeoclimate reconstructions in the Mediterranean region.

\section{Conclusions}

Recent work using a range of geochronological techniques has produced contrasting results for the timing of the glacier maxima across the Mediterranean mountains. Two scenarios have emerged. These suggest: 
1. Early local glacier maxima several thousand to tens of thousands of years earlier than the global LGM (ca. 18 ${ }^{14} \mathrm{C}$ ka BP/ 21 cal. ka BP) of MIS 2. This is based on radiocarbon, $\mathrm{U}$-series and $\mathrm{OSL}$ dating in the Cantabrian Mountains, Pyrenees, Italian Apennines and Pindus Mountains.

2. Local glacier maxima correlating closely with the global LGM. This is based on ${ }^{10} \mathrm{Be}$ and ${ }^{36} \mathrm{Cl}$ cosmogenic isotope analyses from the mountains of central Spain, the Pyrenees, the Maritime Alps and the mountains of western and eastern Turkey.

The first scenario is consistent with biological records from long lacustrine sequences which indicate severe aridity around the time of the global LGM that would have hindered glacier development in the Mediterranean mountains. It is also consistent with the observations of Gillespie and Molnar (1995), who noted the asynchroneity of glacier maxima between continental and mountain glaciers around the world as a result of the particular sensitivity of mountain glaciers to regional climate as well as global conditions. Since Mediterranean glaciers were relatively small in size they would have reached their maximum extent before the much larger ice sheets of the Alps and northern Europe. Moreover, it is likely that increasing ice cover over the Alps and northern Europe, and the southward migration of dominant polar-continental anticyclonic conditions, would have pushed cyclones to the southern edge of the Mediterranean basin and along the North African coast. Mediterranean mountain glaciers in southern Europe are likely to have been starved of moisture at this time and undergone retreat.

The second scenario runs counter to the climatic scenario outlined above. In this situation, the maximum extent of some Mediterranean mountain glaciers appears to have coincided with the peak in global ice volume indicated in the marine isotope record. Glacier maxima at this time in the Mediterranean mountains would have coincided with the driest conditions of the last cold stage. A lack of moisture would have required exceptionally low summer temperatures to sustain these glaciers. This is counter to glacier-climate simulations for local glacier maxima in areas such as Greece (Hughes et al., 2006d). However, in western Turkey, a cold and wet climate has been inferred from local mountain glaciers coinciding with the LGM (Sarıkaya et al., 2008).

Of course, it is possible that regional mass balances and glacier dynamics could have varied across the different parts of the Mediterranean and that the two scenarios outlined above could coexist side by side. This is certainly plausible when comparing areas separated by great distance such as the easternmost dated sequences in Turkey (Akçar et al., 2007, 2008) with those in the western Mediterranean. However, where different geochronologies from the same region are in conflict, then there is an obvious problem of choosing which geochronology is correct - such as in the Pyrenees (Pállas et al., 2007). The same is true of conflicting palaeoclimatic interpretations of glacial records with similar geochronologies (e.g. Akçar et al., 2007, 2008; Sarıkaya et al., 2008).

In addition to the issues relating to the maximum extent of glaciers during the last cold stage, important new evidence is becoming available for glaciation during the Younger Dryas in the Mediterranean. This includes geochronological data from glacial landforms in the Maritime Alps (Federici et al., 2008) the Italian Apennines (Giraudi and Frezzotti, 1997), Montenegro (Hughes and Woodward, this paper) and northeastern Turkey (Akçar et al., 2007). Future progress in understanding the glacial history of the Mediterranean mountains during the last cold stage will require multiple dating techniques to be applied in order to rigorously test the glacial geochronologies. The wider application of different geochronological techniques to other areas of the Mediterranean will no doubt generate new research questions and challenge current views on the timing and palaeoclimatic significance of glaciation in the Mediterranean mountains.

Acknowledgements We thank Nick Scarle for drafting the figures. We would like to thank Professor Glenn Thackray for inviting us to participate in the INQUA Mountain Glacier Research Project. This paper was facilitated by funding by the United States National Science Foundation and International Union for Quaternary Research. U-series ages from Montenegro were funded by the UK Natural Environment Research Council (reference IP/878/1105) and were undertaken at the NERC Useries Facility at the Open University in Milton Keynes, UK, in collaboration with Peter van Calsteren and Louise Thomas. Fieldwork in Montenegro was kindly supported by the Royal Geographical Society (with Institute of British Geographers) with a Peter Fleming Award.

\section{References}

Akçar N, Yavuz V, Ivy-Ochs S, Kubik PW, Vardar M, Schlüchter C. 2007. Paleoglacial records from Kavron Valley, NE Turkey: field and cosmogenic exposure dating evidence. Quaternary International 164-165: 170-183.

Akçar N, Yavuz V, Ivy-Ochs S, Kubik PW, Vardar M, Schlüchter C. 2008. A case for a down wasting mountain glacier during Termination I, Verçenik Valley, NE Turkey. Journal of Quaternary Science 23: 273-285.

Allen JRM, Brandt U, Brauer A, Hubberten HW, Huntley B, Keller J, Kraml M, Mackensen A, Mingram J, Negendank JFW, Nowaczyk NR Oberhansli H, Watts WA, Wulf S, Zolitschka B. 1999. Rapid environmental changes in southern Europe during the last glacial period. Nature 400: 740-743.

Allen JRM, Watts WA, Huntley B. 2000. Weichselian palynostratigraphy, palaeovegetation and palaeoenvironment: the record from Lago Grande di Monticchio, southern Italy. Quaternary International 73: 91-110.

Andrieu V, Hubschmann J, Jalut G, Herail G. 1988. Chronologie de la déglaciation des Pyrénées française. Bulletin de l'Association Française pour l'etude du Quaternaire 2-3: 55-67.

Bar Matthews M, Ayalon A, Kaufman A, Wasserburg GJ. 1999. The Eastern Mediterranean paleoclimate as a reflection of regional events: Soreq cave, Israel. Earth and Planetary Science Letters 166: 85-95.

Boenzi F, Palmentola G. 1997. Glacial features and snow-line trend during the last glacial age in the Southern Apennines (Italy) and on Albanian and Greek mountains. Zeitschrift für Geomorphologie 41: 21-29.

Bordonnau J. 1992. Els complexos glacios-lacustres relacionats amb el darrer cicle glacial als pirineus. Geoforma Ediciones: Logroño.

Cacho I, Grimalt JO, Pelejero C, Canals M, Sierro FJ, Flores JA, Shackleton NJ. 1999. Dansgaard-Oeschger and Heinrich event imprints in Alboran Sea palaeotemperatures. Palaeoceanography 14: 698-705.

Çiner A. 2004. Turkish glaciers and glacial deposits. In Quaternary Glaciations: Extent and Chronology. Part I: Europe, Ehlers J, Gibbard PL (eds). Elsevier: Amsterdam; 419-429.

CLIMAP Project Members. 1976. The surface of ice-age earth. Science 191: 1131-1137.

COHMAP Members. 1988. Climatic changes of the last 18000 years: observations and model simulations. Science 241: 1043-1052.

Daveau S. 1971. La Glaciation de la Serra de Estrela. Finisterra, Revista portuguesa de geografia (Centro de Estudos Geográficos, Faculdade de Letras, Universidade de Lisboa) 6: 5-40.

Ehlers J. 1996. Quaternary and Glacial Geology. Wiley: Chichester. Etlicher B, De Goer de Hervé A. 1988. La déglaciation würmienne dans le Massif Central française: le point des travaux recents. Bulletin de I'Association française pour l'Etude du Quaternaire 34-35: 103-110. 
Federici PR, Pappalardo M. 1995. L'evoluzione recente dei ghiacciai delle Alpi Maritime. Geografia Fisica e Dinamica Quaternaria 18: 257-269.

Federici PR, Granger DE, Pappalardo M, Ribolini A, Spagnolo M, Cyr AJ. 2008. Exposure age dating and Equilibrium Line Altitude reconstruction of an Egesen moraine in the Maritime Alps, Italy. Boreas 37: 245-253.

Fernadez Mosquera D, Marti K, Vidal Romani JR, Weigel A. 2000. Late Pleistocene deglaciation chronology in the NW of the Iberian Peninsula using cosmic-ray produced $21 \mathrm{NE}$ in quartz. Nuclear Instruments and Methods in Physics Research B172: 832-837.

Florineth D, Schlüchter C. 2000. Alpine evidence for atmospheric circulation patterns in Europe during the last glacial maximum. Quaternary Research 54: 295-308.

Fontugne M, Kuzucuoğlu C, Karabıyıkoğlu M, Hatte C, Pastre JF. 1999. From Pleniglacial to Holocene: a ${ }^{14} \mathrm{C}$ chronostratigraphy of environmental changes in the Konya Plain, Turkey. Quaternary Science Reviews 18: 573-591.

García-Ruiz JM, Valero-Garcés BL, Martí-Bono C, González-Sampériz P. 2003. Asynchroneity of maximum glacier advances in the central Spanish Pyrenees. Journal of Quaternary Science 18: 61-72.

Gillespie A, Molnar P. 1995. Asynchronous maximum advances of mountain and continental glaciers. Reviews of Geophysics 33: 311364.

Giraudi C, Frezzotti M. 1997. Late Pleistocene glacial events in the Central Appenines, Italy. Quaternary Research 48: 280-290.

González-Sampériz P, Valero-Garcés BL, Moreno A, Jalut G, GarcíaRuiz JM, Martí-Bono C, Delgado-Huertas A, Navas A, Otto T, Dedoubat JJ. 2006. Climate variability in the Spanish Pyrenees during the last $30000 \mathrm{yr}$ revealed by the El Portalet sequence. Quaternary Research 66: 38-52.

Granger DE, Spagnolo M, Federici P, Pappalardo M, Ribolini A, Cyr AJ. 2006. Last glacial maximum dated by means of ${ }^{10} \mathrm{Be}$ in the Maritime Alps (Italy). In Eos Transactions: American Geophysical Union 87, Fall Meeting Supplement, Abstract H53B-0634.

Hagedorn J. 1969. Beiträge zur Quartärmorphologie griechischer Hochgebirge. Göttinger Geographische Abhandlungen, 50. Goltze: Göttingen.

Hamlin RHB, Woodward JC, Black S, Macklin MG. 2000. Sediment fingerprinting as a tool for interpreting long-term river activity: the Voidomatis basin, Northwest Greece. In Tracers in Geomorphology, Foster IDL (ed.). Wiley: Chichester; 473-501.

Hughes PD. 2007. Recent behaviour of the Debeli Namet glacier, Durmitor, Montenegro. Earth Surface Processes and Landforms 32: 1593-1602.

Hughes PD, Woodward JC, Gibbard PL. 2006a. Glacial history of the Mediterranean mountains. Progress in Physical Geography 30: 334364.

Hughes PD, Woodward JC, Gibbard PL, Macklin MG, Gilmour MA, Smith GR. 2006b. The glacial history of the Pindus Mountains, Greece. Journal of Geology 114: 413-434.

Hughes PD, Woodward JC, Gibbard PL. 2006c. The last glaciers of Greece. Zeitschrift für Geomorphologie 50: 37-61.

Hughes PD, Woodward JC, Gibbard PL. 2006d. Late Pleistocene glaciers and climate in the Mediterranean region. Global and Planetary Change 46: 83-98.

Ivy-Ochs S, Schäfer J, Kubik PW, Synal H-A, Schlüchter C. 2004. Timing of deglaciation on the northern Alpine foreland (Switzerland). Eclogae Geologicae Helvetiae 97: 47-55.

Jalut G, Andrieu V, Delibrias G, Fontugne M, Pagès P. 1988. Palaeoenvironment of the Valley of Ossau (Western French Pyrénées) during the last 27000 years. Pollen et Spores 30: 357-394.

Jalut G, Montserrat J, Fontunge M, Delibrias G, Vilaplana J, Juliá R. 1992. Glacial to interglacial vegetation changes in the northern and southern Pyrenees: deglaciation, vegetation cover and chronology. Quaternary Science Reviews 11: 449-480.

Jiménez-Sánchez M, Farias P. 2002. New radiometric and geomorphologic evidence of Last Glacial maximum older than $18 \mathrm{ka}$ in SW European Mountains: the example of Redes Natural Park Cantabrian Mountains, NW Spain. Geodinamica Acta 15: 93-101.

Kotarba A, Hercman H, Dramis F. 2001. On the age of Campo Imperatore glaciations, Gran Sasso Massif, Central Italy. Geografia Fisica e Dinamica Quaternaria 24: 65-69.
Kuzucuoğlu C, Roberts N. 1998. Evolution de l'Environment en Anatolie, de 2000 à 6000 BP. Paleorient 23: 7-24.

Lawson IT, Frogley M, Bryant C, Preece R, Tzedakis PC. 2004. The Lateglacial and Holocene environmental history of the loannina basin, north-west Greece. Quaternary Science Reviews 23: 1599-1625.

Lewin J, Macklin MG, Woodward JC. 1991. Late Quaternary fluvial sedimentation in the Voidomatis Basin, Epirus, northwest Greece. Quaternary Research 35: 103-115.

Liedtke H. 1962. Eisrand und Karstpoljen am Westrand LukavicaHochfläche. Erdkunde 16: 289-298.

Mardones M, Jalut G. 1983. La Tourbière de Biscaye (Alt. $409 \mathrm{~m}$, Hautes Pyrénées): approche paléoécologique des 45000 dernières années. Pollen et Spores 25: 163-212.

Martinson DG, Pisias NG, Hays JD, Imbrie J, Moore TC, Shackleton NJ. 1987. Age dating and the orbital theory of the ice ages: development of a high resolution 0-300 000 year chronostratigraphy. Quaternary Research 27: 1-29.

Mastronuzzi G, Sanso P, Stamatopoloulos L. 1994. Glacial landforms of the Peloponnisos Greece. Rivista Geografica Italiana 101: 77-86.

Menkovic L, Markovic M, Cupkovic T, Pavlovic R, Trivic B, Banjac N. 2004. Glacial morphology of Serbia, with comments on the Pleistocene glaciation of Montenegro, Macedonia and Albania. In Quaternary Glaciations: Extent and Chronology. Part I: Europe, Ehlers J, Gibbard PL (eds). Elsevier: Amsterdam; 379-384.

Messerli B. 1967. Die eiszeitliche und die gegenwartige Vertgletscherung im Mittelemeeraum. Geographica Helvetica 22: 105-228.

Monegato G, Ravazzi C, Donegana M, Pini R, Calderoni G, Wick L. 2007. Evidence of a two-fold glacial advance during the last glacial maximum in the Tagliamento end moraine system (eastern Alps). Quaternary Research 68: 284-302.

Montserrat JM. 1992. Evolución glaciar y postglaciar del clima y la vegetación en la vertiente sur del Pirineo: estudio palinológico. Monografías del Instituto Pirenaico de Ecologia, 6, Consejo Superior de Investigaciones Científicas, Zaragoza, Spain.

Palacios D, Marcos J, Andrés N, Vázquez L. 2007. Last glacial maximum and deglaciation in central Spanish mountains. Geophysical Research Abstracts 9: 05634.

Pallàs R, Rodés Á, Braucher R, Carcaillet J, Ortuño M, Bordonau J, Bourlès D, Vilaplana JM, Masana E, Santanach P. 2007. Late Pleistocene and Holocene glaciation in the Pyrenees: a critical review and new evidence from ${ }^{10} \mathrm{Be}$ exposure ages, south-central Pyrenees. Quaternary Science Reviews 25: 2937-2963.

Peña JL, Sancho C, Lewis C, McDonald E, Rhodes E. 2004. Datos cronológicos de las morrenas terminals del glaciar del Gállego y su relación con las terrazas fluvioglaciares (Pirineo de Huesca). In Geografía Física de Aragón, Aspectos generales y temáticos, Peña JL, Longares LA, Sánchez M (eds). Universidad de Zaragoza e Institución Fernando el Católico: Zaragoza; 71-84.

Ponel P, Andrieu-Ponel V, Parchoux F, Juhasz I, De Beaulieu J-L. 2001. Late-glacial and Holocene high-altitude environmental changes in Vallee des Merveilles Alpes-Maritimes, France: insect evidence. Journal of Quaternary Science 16: 795-812.

Pons A, Reille M. 1988. The Holocene- and Upper Pleistocene pollen record from Padul (Granada, Spain): a new study. Palaeogeography, Palaeoclimatology, Palaeoecology 66: 243-263.

Prentice IC, Guiot J, Harrison SP. 1992. Mediterranean vegetation, lake levels and palaeoclimate at the Last Glacial Maximum. Nature 360: 658-660.

Reille M, Andrieu V. 1995. The late Pleistocene and Holocene in the Lourdes Basin, Western Pyrénées, France: new pollen analytical and chronological data. Vegetation History and Archaeobotany 4: 1-21.

Sancho C, Peña Monné JL, Lewis C, McDonald E, Rhodes E. 2002. Preliminary dating of glacial and fluvial deposits in the Cinca River Valley (NE Spain): chronological evidences for the Glacial Maximum in the Pyrenees?. In Quaternary Climatic Changes and Environmental Crises in the Mediterranean Region, Ruíz-Zapata B, Dorado-Valiño M, Valdemillos A, Gil-García MJ, Badají T, Bustamante I, Mendizábal I (eds). Universidad de Alcalá de Henares: Madrid; 453-456.

Sarıkaya MA, Zreda M, Çiner A, Zweck C. 2008. Cold and wet Last Glacial Maximum on Mount Sandıras, SW Turkey, inferred from cosmogenic dating and glacier modelling. Quaternary Science Reviews 27: 769-780. 
Sawicki RVon. 1911. Die eiszeitliche Vergletscherung des Orjen in Süddalmatien. Zeitschrift für Gletscherkunde 5: 339-355.

Seret G, Dricot J, Wansard G. 1990. Evidence for an early glacial maximum in the French Vosges during the last glacial cycle. Nature 346: 453-456.

Smith GW, Nance RD, Genes AN. 1997. Quaternary glacial history of Mount Olympus. Geological Society of America Bulletin 109: 809824.

Turner C, Hannon GE. 1988. Vegetational evidence for late Quaternary climatic changes in southwest Europe in relation to the influence of the North Atlantic Ocean. Philosophical Transactions of the Royal Society, London B318: 451-485.

Tzedakis PC. 1999. The last climatic cycle at Kopais, central Greece. Journal of the Geological Society 156: 425-434.

Tzedakis PC. 2007. Seven ambiguities in the Mediterranean palaeoenvironmental narrative. Quaternary Science Reviews 26: 2042 2066.

Tzedakis PC, Andrieu V, de Beaulieu J-L, Crowhurst S, Follieri M, Hooghiemstra H, Magri D, Reille M, Sadori L, Shackleton NJ, Wijmstra TA. 1997. Comparison of terrestrial and marine records of changing climate of the last 500000 years. Earth and Planetary Science Letters 150: 171-176.

Tzedakis PC, Lawson IT, Frogley MR, Hewitt GM, Preece RC. 2002. Buffered tree population changes in a Quaternary refugium: evolutionary implications. Science 297: 2044-2047.

Vidal-Romaní JR, Santos L. 1994. La deglaciación finicuaternaria en el noroeste peninsular (Serra de Queixa- Invernadoiro, Ourense, Gali- cia): datos geomorfológicos y paleobotánicos. Cuaternario y Geomorfología 8: 33-44.

Vidal-Romaní JR, Fernández-Mosquera D, Marti K, Brum-Ferreira A. 1999. Nuevos datos para la chronología glaciar pleistocena en el NW de la Península Ibérica. Cuadernos Laboratorio Xeolóxico de Laxe 24: 7-29.

Vieira G, Ferreira AB, Mycielska-Dowgiallo E, Woronko B, Olszak I. 2001. Thermoluminescence Dating of Fluvioglacial Sediments (Serra da Estrela, Portugal). Actas V REQUI-I CQPLI, Lisbon, Portugal, 23 27 July 2001; 85-92.

Vilaplana JM. 1983. Quaternary glacial geology of Alta Ribagorçana Basin (Central Pyrenees). Acta Geológica Hispánica 18: 217-233.

Walker MJC. 2005. Quaternary Dating Methods. Wiley: Chichester.

Woodward JC, Lewin J, Macklin MG. 1992. Alluvial sediment sources in a glaciated catchment: the Voidomatis basin, northwest Greece. Earth Surface Processes and Landforms 16: 205-216.

Woodward JC, Macklin MG, Smith GR. 2004. Pleistocene glaciation in the mountains of Greece. In Quaternary Glaciations: Extent and Chronology. Part I: Europe, Ehlers J, Gibbard PL (eds). Elsevier: Amsterdam; 155-173.

Woodward JC, Hamlin RHB, Macklin MG, Hughes PD, Lewin J. 2008. Pleistocene catchment dynamics in the Mediterranean: glaciation, fluvial geomorphology and the slackwater sediment record. Geomorphology. doi: 10.1016/j.geomorph.2008.05.018

Yokoyama Y, Lambeck K, De Deckker P, Johnston P, Fifield K. 2000. Timing of the Last Glacial Maximum from observed sea-level minima. Nature 406: 713-716. 